\title{
Geometric Modification of a Switched Reluctance Motor for Minimization of Torque Ripple using Finite Element Analysis for Electric Vehicle Application
}

\author{
Sadeep Sasidharan* and T. B. Isha \\ Department of Electrical and Electronics Engineering, Amrita School of Engineering, Coimbatore, Amrita Vishwa Vidyapeetham, \\ India
}

Received 25 October 2018; Accepted 4 April 2019

\begin{abstract}
There is a growing interest in developing Switched Reluctance Motors for electrical traction applications. This is mainly due to the significant advantages as lower cost, better fault tolerance, high reliability possessed by Switched Reluctance Motor (SRM) when compared with any other rare earth motors. But the SRM suffers from a torque ripple problem due to its double saliency and this has limited its use in automotive traction applications. This paper deals with the design of an $8 / 620 \mathrm{~kW}$ SRM used for electric vehicle application and comparison of performance of the conventional motor with that of geometrically optimized SRM. The conventional design method is available in literature. The optimized geometry is modeled using JMAG software and compared with the conventional one for reduced torque ripple. The optimization was done for the air gap, extended pole shoe, fillets and circular windows for reduced torque ripple. The simulation shows a reduced torque ripple for the optimized geometry.
\end{abstract}

Keywords: Optimization, Switched Reluctance Motor, Electric Vehicle, Energy conversion

\section{Introduction}

There has been a rapid resurgence in the research of SRM for electric vehicle applications. Automotive traction application necessitates higher torque density, performance, reliability, better fault tolerance and lesser costs. SRMs define their advantages with these criteria compared to an induction motor or a rare earth motor [1][2]. However, a wide acceptance of SRM is limited in the automotive field owing to its weight, torque ripple and acoustic noise unlike other type of motors of the same rating [3].

In this paper, a simulation study is made on the torque ripple minimization of SRM. Torque ripple minimization can be carried out at both the design level and control level. Numerous methods are available in literature. During early 2000's, Electrical and geometrical optimization of SRM based on progressive quadratic response surface method was done by Choi, J.H., Kim, T.H., Jang, K.B. and Lee, J.[4]. This paper compared the PQRS method with the well known gradient method, showed an improvement of three times over the conjugate gradient method. A new rotor shape for SRM was proposed for reducing torque ripple in the year 2004 [5]. A rotor with notched teeth was studied in this paper and torque ripple was seen to reduce by $4.4 \%$ from the conventional design. In the year 2007, pole shape optimization of the stator pole was done by Choi, Y.K., Yoon, H.S. and Koh, C.S. [6]. The effects of each design parameters were investigated using Finite Element Analysis. The torque ripple is reduced by $23 \%$. A multi objective optimization technique for reduced torque ripple was done by Nabeta S.I., Chabu I.E., Lebensztajn L., Correa, D.A.P,

*E-mail addresssadeepsasidharan@gmail.com ISSN: $1791-2377$ @ 2019 Eastern Macedonia and Thrace Institute of Technology. All rights reserved. doi:10.25103/iestr.122.11
Da Silva W.M. and Hameyer K. [7]. Finite element simulation was used to reduce the torque ripple and the system was shown to give higher torque density and lesser torque ripple. A survey paper on torque ripple minimization techniques of an SRM drive was done in 2010 [8]. This paper presents an extensive review of the origin of torque ripple and the approaches used for the minimization of torque ripple considering various design and control methods. Later, in the year 2016, a novel cylindrical outer rotor shape was considered for reducing torque ripple in SRM by K. Kiyota, T. Kakishima, A. Chiba and M. A Rahman [9]. Torque ripple, acoustic noise and windage loss were seen to reduce at certain drive points only. Recently, after 2018 numerous studies have been done on the design optimization of SRM for Electric traction applications. A high speed 20kW 18/12 SRM with asymmetrical bridge converter was proposed by A. A. S Bukhari and his team by using finite element analysis [10]. The developed prototype was shown to have high starting torque with higher speed and was seen suitable for light EVs. The motor also showed best average torque with a reduced torque ripple for $50 \%$ slot fill factor. In the same year, F. J Marquez Fernandez et al. proposed a 2 phase axial flux machine for traction application [11]. This study involved both segmented stator and rotor core. The tests showed good performance at low current values for high speed traction applications. An approach on the modular structure of SRM having modular stator and rotor structures using finite element analysis was proposed by S. A Ansari et al. [12]. The output torque was seen to increase by $18 \%$ from the conventional design with a decrease in the outer diameter of the machine by $20.8 \%$. Another study focused on the design of pole arcs, Q Sun et al. designed a double stator SRM with multiple pole arcs for reducing the torque ripple in conventional SRMs [13]. 
The potential pole arcs are identified first followed by the optimization to arrive at the best possible pole arc combination for higher torque and reduced torque ripple. The design of a novel Hybrid SRM was done by J Zhu et al. by using permanent magnets for improved torque [14]. The proposed model was compared with a conventional SRM and seen to have higher average torque and reduced torque ripple. $M$ Belhadi et al. proposed a new approach to reduce torque ripple for automotive applications by optimizing the motor structure [15]. The operating points are optimized using finite element analysis as well as fourier transformation. Core modification was also considered by $\mathrm{M}$ Aydemir et al. using a double U core SRM [16]. The torque ripple was found to reduce by large amounts at specific speeds. Optimization technique was also considered by $\mathrm{H}$ Chen et al. for SRM used in EV application [17]. A swarm optimization algorithm was used to arrive at the best possible design for reduced torque ripple factor. Lately new winding configuration and power converter combinations were also considered which was found to bring down torque ripple by considerable amount [18][19]. Geometrical modifications in SRM are considered to have a direct impact on the torque ripple minimization based on the literature.

Torque ripple minimization by PWM current control was done by I Husain and M Ehsani in the year 1996 [20]. This paper presents a new strategy of PWM current control for smooth operation of the drive. This method includes a current control strategy during commutation when torque ripple minimization is of utmost importance. S Mir, M.E Elbuluk and I Husain carried out the Torque-ripple minimization in SRMs using adaptive fuzzy control in 1999 [21]. The torque is generated over the maximum positive torque-producing region of a phase and showed increased torque density. Five new optimization procedures for minimization of the torque ripple in a SRM was done in 2005 [22]. Torque ripple is seen to reduce, but by a very small amount. V P Vujicic devised a technique for torque ripple minimization in SRM using the torque sharing function concept [23]. In 2015, torque ripple free operation of PM BLDC drives was done with petal wave current supply [24]. Torque performance was found to improve with this method. Several methods based on the PWM control strategy and torque sharing function were found helpful in reducing torque ripple in SRM recently [25][26]. A comparison between the DTC and DITC control techniques was shown in [27]. DITC was seen to reduce the torque ripple considerably compared to DTC. An improvement over the DTC technique was proposed in [28] by removing the hysteresis loop control of flux and selecting new voltage rules. The torque ripple was seen to reduce from $38.33 \%$ to $16.67 \%$ by increasing the torque-ampere ratio. More recently, torque position based current modelling and model predictive control techniques have been considered in reducing torque ripple in SRM [29][30]. M Debouza et al. proposed a novel grey wolf optimization technique to optimize the SRM converter firing pulses to produce the lowest possible torque ripples [31]. The optimum value of the objective function to reduce torque ripple was found to be 0.98167 . A review of the torque ripple minimization techniques was done by G Velmurugan et al. recently based on machine design changes and novel control strategies [32].

This paper is organized into four sections. The conventionally designed motor and its performance is given in section 2. Section 3 focusses on the optimized geometry of SRM and its performance followed by conclusion and future scope in section 4 .

\section{SRM model}

Design procedure for the developed SRM is carried out, considering a conventional electric vehicle Mahindra REVA available in India [33]. The previous work of the authors deals with the design of the conventional electric vehicle based on the forces acting on the vehicle system. This leads to a SRM of $20 \mathrm{~kW}$ power rating [39]. Basic design of a $\mathrm{SRM}$ is given in [34][35][36]. Design data of the $20 \mathrm{~kW}$ $\mathrm{SRM}$ is given in Table 1 .

$\underline{\text { Table .1. Motor design data }}$

\begin{tabular}{c|c}
\hline Motor data & $\begin{array}{c}\text { Switched Reluctance } \\
\text { Machine }\end{array}$ \\
\hline $\begin{array}{c}\text { Outer/inner stator diameter } d_{\mathrm{sa}} / d_{\mathrm{si}} \\
\text { (mm }\end{array}$ & $250 / 132.9$ \\
$d_{\mathrm{ra}} / \delta(\mathrm{mm})$ & $132.5 / 0.2$ \\
$Q_{\mathrm{s}} / Q_{\mathrm{r}}$ & $8 / 6$ \\
Toter rotor diameter/ air gap & \\
Stack length $l_{\mathrm{Fe}}(\mathrm{mm})$ & 300 \\
Stator resistance per phase $(20$ & 0.85 \\
$\left.{ }^{\circ} \mathrm{C}\right) R_{\mathrm{s}}(\mathrm{Ohm})$ & \\
Armature winding / slot fill & One coil per stator tooth / \\
factor & 46.78 \\
Number of turns per phase $N_{\mathrm{s}}$ & 40 \\
Rotor moment of inertia & $0.0195 \mathrm{kgm}^{2}$ \\
Shaft diameter $(\mathrm{mm})$ & 47.22 \\
Rated Speed (rpm) & 2750 \\
Power $(\mathrm{W})$ & 20000 \\
Rated current $(\mathrm{A})$ & 38 \\
\hline
\end{tabular}

JMAG software is used for the Finite Element Analysis (FEA) of the designed $8 / 620 \mathrm{~kW}$ SRM. Mesh analysis is done based on the accuracy requirement for the simulation. Here, almost 2,00,000 meshes have been considered for improved accuracy of FEA. The mesh analysis is carried out for a speed of $2750 \mathrm{rpm}$, the base speed rating of the Electric vehicle considered. The mesh diagram of the half section of the SRM is shown in Fig. 1

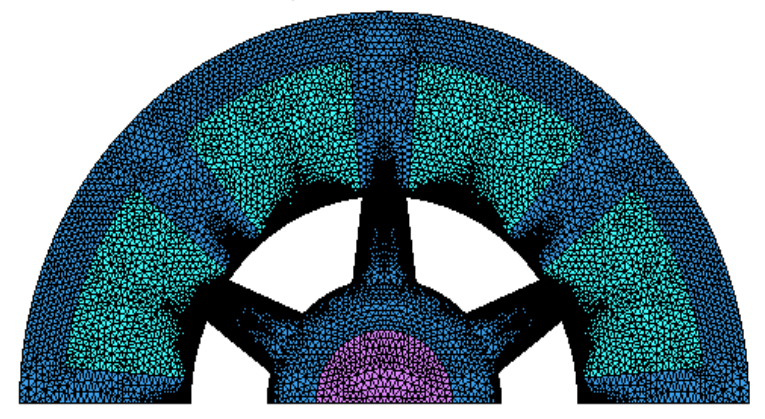

Fig. 1 Meshed SRM for FEA

Torque-speed characteristics of the 20kW SRM is shown in Fig. 2. Starting torque of $290 \mathrm{Nm}$ is achieved by the system. It can be seen that the motor has a very wide operating range over entire region of operation. At the base speed, the torque is almost $80 \mathrm{Nm}$. The torque profile is seen to match the Electric Vehicle Torque-Speed Characteristics.

Power-speed curve of the 20kW SRM is shown in Fig. 3. It shows a peak power rating of $33 \mathrm{~kW}$. Power rating of $22 \mathrm{~kW}$ is achieved at the base speed rating of $2750 \mathrm{rpm}$. The power is very well maintained throughout the entire range of operation. 


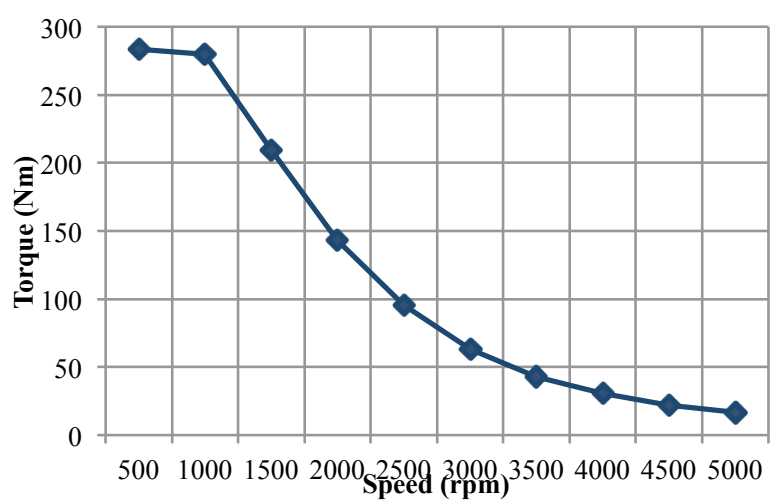

Fig.2 Torque-speed characteristics

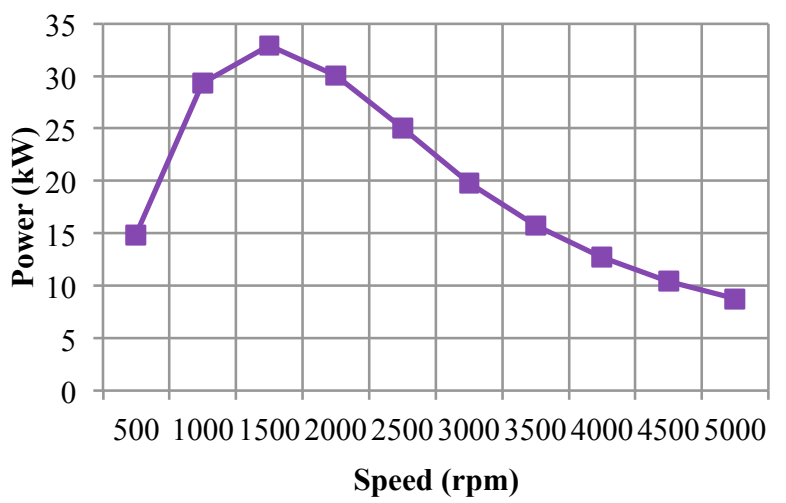

Fig.3 Power-speed characteristics

Fig. 4 shows the efficiency-speed curve of the $20 \mathrm{~kW}$ SRM. Peak efficiency occurs at $1250 \mathrm{rpm}$ and the efficiency at the base speed is $88 \%$.

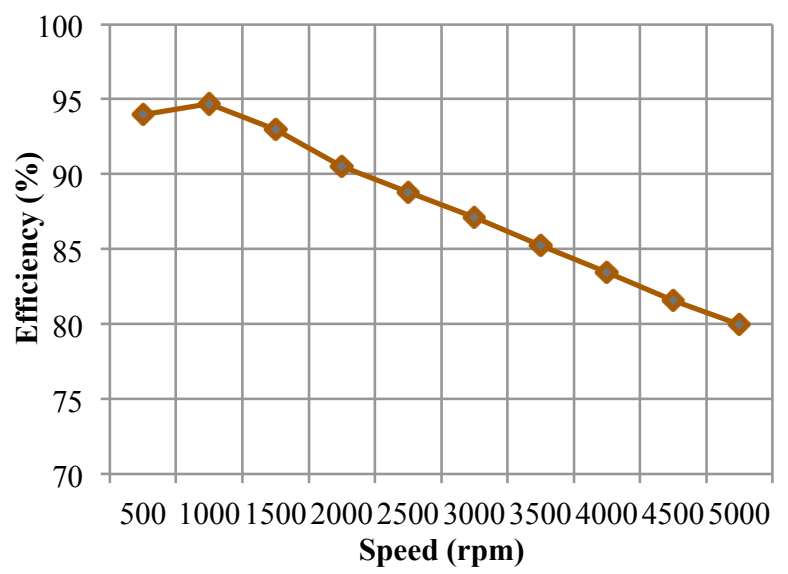

Fig. 4 Efficiency-speed characteristics

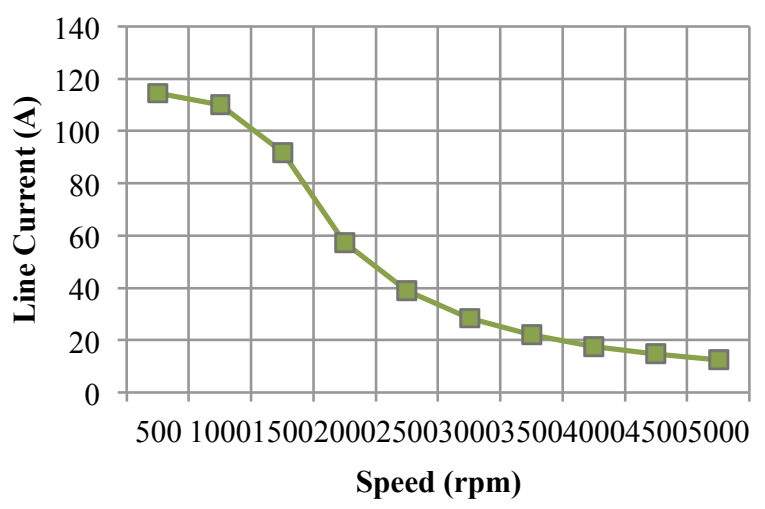

Fig. 5 Line current-speed characteristics
The line current-speed curve is given in Fig. 5. The maximum current is found to be nearly $120 \mathrm{~A}$.

The torque profile at 2750rpm given in Fig. 6 shows a continuous torque rating of around $72 \mathrm{Nm}$ for the switching operation at the base speed of $2750 \mathrm{rpm}$ which is more than the expected torque rating of $69.48 \mathrm{Nm}$ at the base speed.

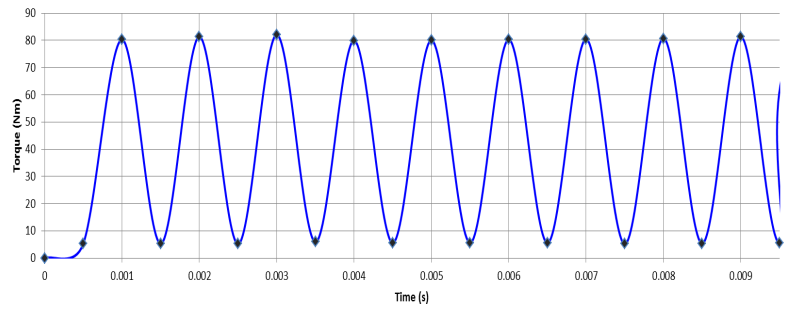

Fig.6 Torque profile at 2750rpm

The torque ripple in an SRM can be written as

Torque $_{\text {ripple }}=\frac{\text { Torque }_{\max }-\text { Torque }_{\text {min }}}{\text { Torque }_{\text {average }}}$

For the given design, Torque ripple $_{\text {obtained by }}$ calculation is found to be $168 \%$ a large value.

\section{Optimization approach}

The model shown in Fig. 1 exhibits a torque ripple of $148 \%$. A design based optimization technique is adopted inorder to reduce the torque ripple. The $3 \mathrm{D}$ model of the optimized SRM is shown in fig. 7.

Radial force is one of the main reason for increased torque ripple. The value of radial force increases from minimum to maximum value from the unaligned position to the aligned position. Here a modification of rotor poles is tried by providing holes on the pole faces. Holes in the rotor pole helps in the reduction of radial force, thereby reducing the torque ripple. But the torque density is affected marginally by the hole. A significant reduction in frequency of the occurrence of torque ripple can be achieved by the holes in rotor pole. By trial and error, a hole at a position approximated to $3 / 4$ the length of the rotor pole was shown to give the least torque ripple while maintaining the best torque performance. Radial force is reduced by reducing the overlap between the rotor and stator pole. Hence, the hole is preferably aligned near the surface of the rotor pole.

The distance from the centre of the rotor shaft to the centre of the circular window is calculated for reduced radial force. The circular window in the SRM is shown in fig. 8. It is seen that the radial force is affected only by the width of the rotor pole and not by its thickness. Centre of the circular window is found as rotor radius $-3 / 4$ rotor radius, which is calculated as $33.125 \mathrm{~mm}$. Diameter of the circular window is taken as $2 \mathrm{~mm}$, as trial and error gives this width as providing the most reduced radial force.

By applying Lorentz equation,

Volume force density, $F=J \times B$

Where $\mathrm{J}$ is current density and $\mathrm{B}$ is the flux density

Radial Force, $F_{r}=\iint \frac{1}{2 \mu_{0}} \nabla B^{2} n d S$

$F_{r}=\iint\left(B_{r}{ }^{2}-B_{t}{ }^{2}\right) d S, B_{r}$ is the radial flux and $B_{t}$ is the tangential flux 
$\mathrm{S}$ is the surface over which the radial force is exerted

Let the design factor, $N=\frac{T_{\text {average }}}{F_{r}}$

$N=\frac{\beta_{\text {overlap }}}{\delta_{\text {airgap }}}$

Hence, $\frac{T_{\text {average }}}{F_{r}}=\frac{\beta_{\text {overlap }}}{\delta_{\text {airgap }}}, \delta_{\text {airgap }}$ is the air gap radius and $\beta_{\text {overlap }}$ is the overlap arc

From [19], $F_{r} \propto \frac{1}{l_{\text {airgap }}}$

Where $l_{\text {airgap }}$ is the air gap length

$T_{\text {average }} \propto i^{2}$

By increasing the airgap by $0.1 \mathrm{~mm}$ from that of the conventional model, the radial force and the torque ripple is found to reduce. A trade off is necessary between the current and the increase in air gap because the motor has to draw in a higher current to produce the required torque. It can be see that there is not much of an increase in the current when the air gap is increased by $0.1 \mathrm{~mm}$. A further optimization is tried by incorporating an extended filleted stator pole shoes as shown in fig. 9 .

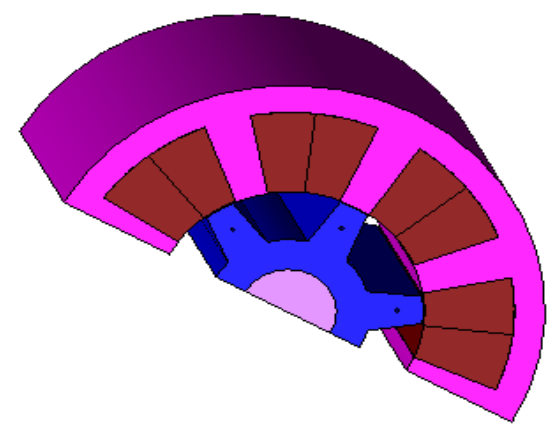

Fig.7 SRM model with rotor pole hole and extended filleted stator pole shoes

Shoes are provided to the stator and the stator and rotor poles are filleted for smoother transition of forces along the edges [37][38]. The tooth angle width for the stator pole shoe is set as 35 degree as shown in Fig. 9 for smoothening the overlap between the stator and rotor which thereby reduces the torque ripple. The smooth overlap with the 35 degree stator pole shoe is shown to reduce the torque ripple.

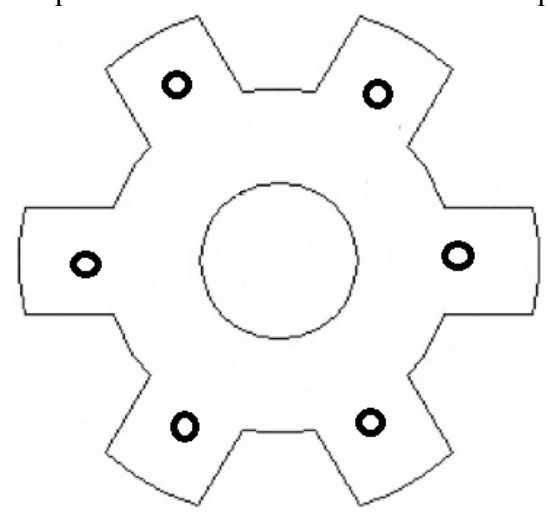

Fig. 8 SRM motor with circular windows

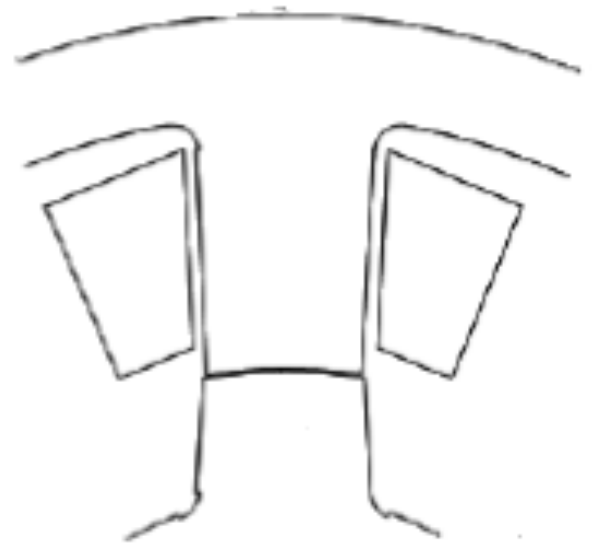

Fig.9 Optimized stator pole shoe with fillets; (a) stator pole conventional; (b) stator pole modified

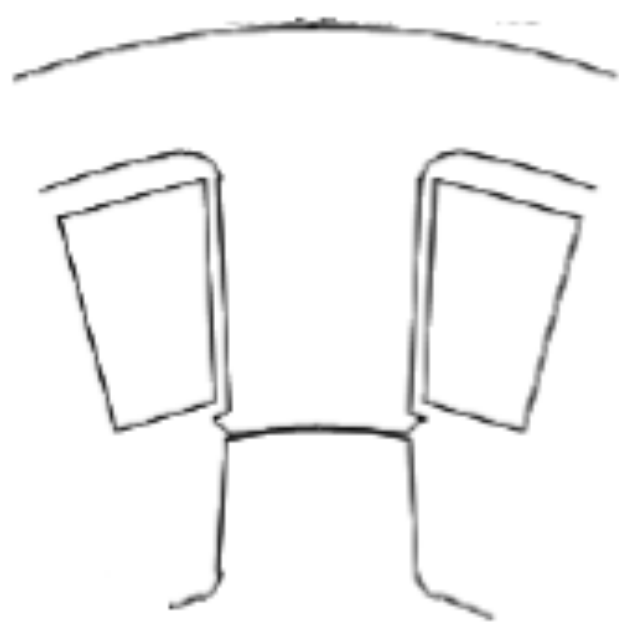

Fig. 10 shows the torque-speed characteristics of the optimized SRM The profile is almost seen to match the torque values at each speed reference points exactly compared to that of the conventional SRM.

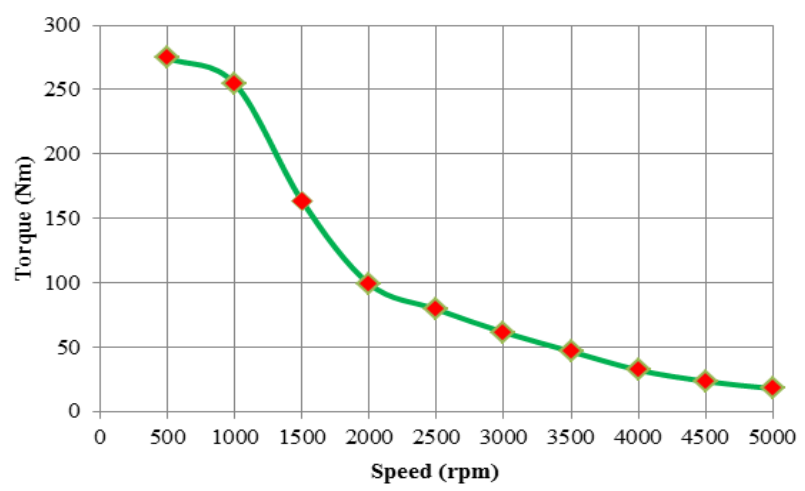

Fig.10 Torque-speed characteristics of the optimized SRM

Fig. 11 shows the efficiency-speed characteristics of the optimized SRM. The peak efficiency is achieved at 1000 $\mathrm{rpm}$. The efficiency at the base speed is seen to decrease to $82 \%$ compared to the existing conventional design because of the optimization in geometry.

The line current-speed curve of the optimized SRM is shown in Fig. 12. The magnitude of the line current is almost $120 \mathrm{~A}$, similar to the conventional design. 


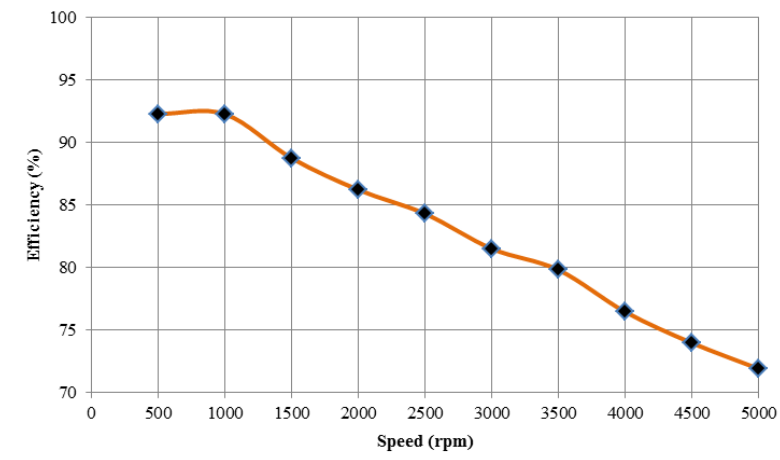

Fig. 11 Efficiency-speed curve of the optimized SRM

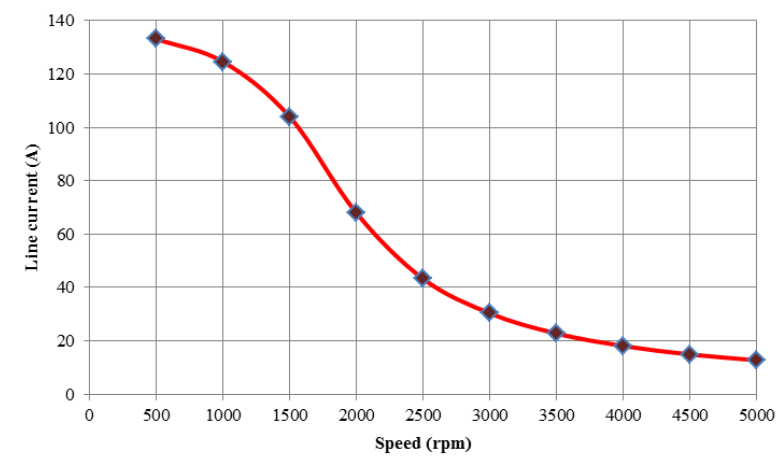

Fig. 12 Line current-speed characteristics of the optimized SRM

The power-speed curve of the optimized SRM is shown in Fig. 13. The peak power rating is found to be $26 \mathrm{~kW}$. The power rating at $2750 \mathrm{rpm}$ is $25 \mathrm{~kW}$. The constant power operation is seen to be improved with compared to that of the conventional design.

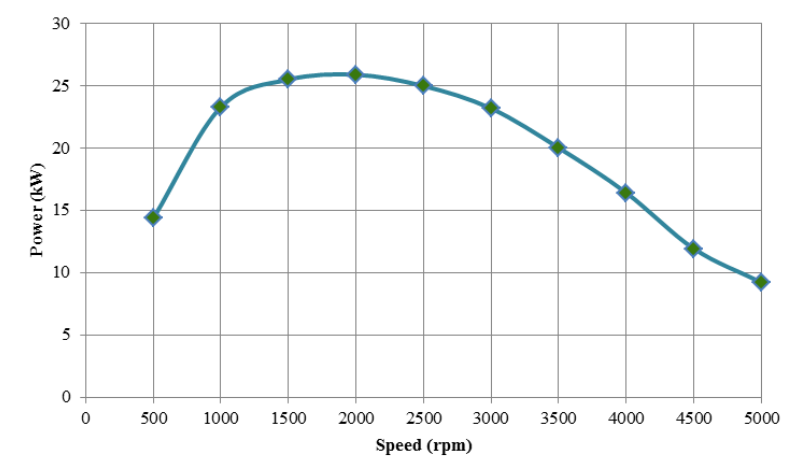

Fig. 13 Power-speed characteristics of the optimized SRM
The torque profile of the optimized SRM is shown in Fig. 14. It is seen that the torque ripple is decreased by around $100 \%$ from the conventional design by the optimization of the geometry.

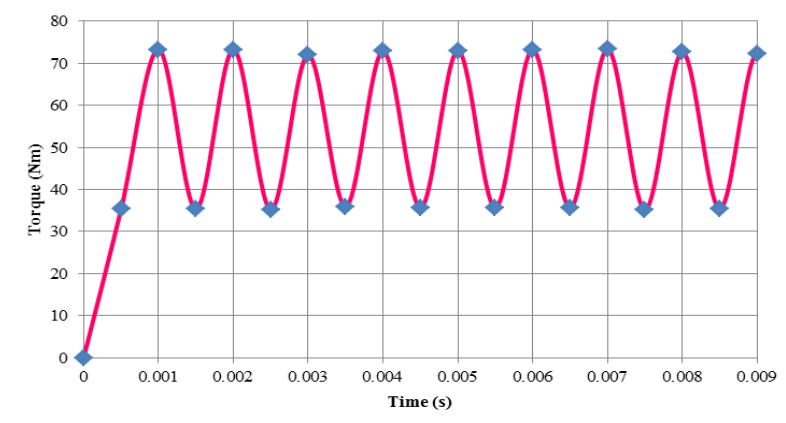

Fig.14 Torque profile of the optimized SRM

\section{Conclusion and future scope}

A $20 \mathrm{~kW} 8 / 6 \mathrm{SRM}$ was modeled using JMAG Designer. The major geometrical dimensions were calculated based on the theoretical design. The machine was simulated using the JMAG Finite Element Analysis and the results are validated with the theoretical design approach. An optimized geometry of the SRMwas formulated for reduction of radial force and torque ripple. The approach was based on increasing the length of the air gap, providing circular windows on the rotor pole and smoothening the transition between rotor and stator by providing stator pole shoes and filleting the rotor and stator. The parameters are evaluated by keeping a proper tradeoff between the parameters and the torque density. The optimized geometry gave reduced torque ripple by $100 \%$. A slight reduction is observed in the torque density though. A laboratory model of the SRM is being developed for the confirmation of results by hardware. Reduction of torque ripple with a robust controller design is also part of the future scope of work.

This is an Open Access article distributed under the terms of the Creative Commons Attribution License

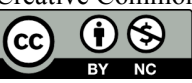

\section{References}

1. Dorrell, D.G., Knight, A.M., Popescu, M., Evans, L. and Staton, D.A., 2010, September. Comparison of different motor design drives for hybrid electric vehicles. In Energy Conversion Congress and Exposition (ECCE), 2010 IEEE (pp. 3352-3359). IEEE.

2. Neudorfer, H., N. Wicker, and A. Binder. "Comparison of three different electric powertrains for the use in hybrid electric vehicles." (2008): 510-514.

3. Zhu, Z. Q., and C. C. Chan. "Electrical machine topologies and technologies for electric, hybrid, and fuel cell vehicles." Vehicle Power and Propulsion Conference, 2008. VPPC'08. IEEE. IEEE, 2008.

4. Choi, J.H., Kim, T.H., Jang, K.B. and Lee, J., 2003. Geometric and electrical optimization design of SR motor based on progressive quadratic response surface method. IEEE transactions on magnetics, 39(5), pp.3241-3243.

5. Lee, J.W., Kim, H.S., Kwon, B.I. and Kim, B.T., 2004. New rotor shape design for minimum torque ripple of SRM using FEM. IEEE transactions on magnetics, 40(2), pp.754-757.
6. Choi, Y.K., Yoon, H.S. and Koh, C.S., 2007. Pole-shape optimization of a switched-reluctance motor for torque ripple reduction. IEEE Transactions on Magnetics, 43(4), pp.1797-1800.

7. Nabeta, S.I., Chabu, I.E., Lebensztajn, L., Correa, D.A.P., Da Silva, W.M. and Hameyer, K., 2008. Mitigation of the torque ripple of a SRM through a multiobjective optimization. IEEE Transactions on Magnetics, 44(6), pp.1018-1021.

8. Evangeline, S. Jebarani, and S. Suresh Kumar. "Torque Ripple Minimization of switched reluctance drives-A survey." 5th IET International Conference on Power Electronics, Machines and Drives (PEMD 2010).

9. K. Kiyota, T. Kakishima, A. Chiba and M. A Rahman, "Cylindrical Rotor Design for Acoustic Noise and Windage Loss Reduction in SRM for HEV Applications", IEEE Transactions on Industry Applications, Vol. 52, No. 1, pp 154-162, January/ February 2016

10. Bukhari, A.A.S., Ali, S., Shaikh, S.H., Soomro, T.A., Lin, Z. and Cao, W., 2018, March. Design of a high speed 18/12 switched reluctance motor drive with an asymmetrical bridge converter for electric vehicles. In 2018 International Conference on Computing, 
Mathematics and Engineering Technologies (iCoMET) (pp. 1-6). IEEE.

11. Márquez-Fernández, F.J., McCulloch, M.D., Potgieter, J.H. and Fraser, A.G., 2018. A novel topology of high-speed SRM for highperformance traction applications. In Workshop SRM Drives an Alternative for E-Traction: Proceedings: February 2, 2018, EPSEVG-UPC Vilanova i la Geltrú (Barcelona) Spain(pp. 47-53). Universitat Politècnica de Catalunya. GAECE-Grup d'Accionaments Elèctrics amb Commutació Electrònica.

12. Kondelaji, M.J., Ansa, S.A., Mirsalim, M. and Moghani, J.S., 2018. Modeling and Analysis of a Modular Switched Reluctance Motor for EV Applications. Electrical Machines Letters, 3(1), pp.1-9.

13. Sun, Q., Wu, J., Gan, C., Shi, C. and Guo, J., 2018. DSSRM Design With Multiple Pole Arcs Optimization for High Torque and Low Torque Ripple Applications. IEEE Access, 6, pp.27166-27175.

14. Zhu, J., Cheng, K.W.E. and Xue, X., 2018. Design and Analysis of a New Enhanced Torque Hybrid Switched Reluctance Motor. IEEE Transactions on Energy Conversion, 33(4), pp.1965-1977.

15. Belhadi, M.H., Krebs, G., Marchand, C., Hannoun, H. and Mininger, X., 2018. Geometrical optimization of SRM on operating mode for automotive application. Electrical Engineering, 100(1), pp.303-310.

16. Aydemir, M., Okumus, H.I. and Aydin, M., 2018, August. Torque Ripple Minimization in Double U Core Switched Reluctance Motor. In 2018 IEEE 18th International Power Electronics and Motion Control Conference (PEMC) (pp. 623-628). IEEE.

17. Chen, H., Yan, W., Gu, J.J. and Sun, M., 2018. Multiobjective Optimization Design of a Switched Reluctance Motor for LowSpeed Electric Vehicles With a Taguchi-CSO Algorithm. IEEE/ASME Transactions on Mechatronics, 23(4), pp.1762-1774.

18. Kilic, O., Elrayyah, A. and Sozer, Y., 2018, March. Torque ripple minimization in SRMs at medium and high speeds using a multistator windings with a novel power converter. In 2018 IEEE Applied Power Electronics Conference and Exposition (APEC) (pp. 1217-1222). IEEE.

19. Kusumi, T., Hara, T., Umetani, K. and Hiraki, E., 2018, September. Rotor Configuration Which Reduces Copper Loss of Switched Reluctance Motors with Suppression of Torque Ripple and Input Current Ripple. In 2018 IEEE Energy Conversion Congress and Exposition (ECCE) (pp. 6097-6103). IEEE.

20. Husain, I. and Ehsani, M., "Torque ripple minimization in SRM drives by PWM current control", IEEE transactions on power electronics, 11(1), pp.83-88, 1996.

21. Mir, S., Elbuluk, M.E. and Husain, I., "Torque-ripple minimization in SRMs using adaptive fuzzy control", IEEE Transactions on Industry Applications, 35(2), pp.461-468, 1999

22. Shaked, N.T. and Rabinovici, R., "New procedures for minimizing the torque ripple in SRMs by optimizing the phase-current profile", IEEE Transactions on magnetics, 41(3), pp.1184-1192, 2005

23. Vujicic, Vladan P. "Minimization of torque ripple and copper losses in switched reluctance drive." IEEE transactions on power electronics 27.1 (2012): 388-399.

24. Buja, Giuseppe, Manuele Bertoluzzo, and Ritesh Kumar Keshri. "Torque ripple-free operation of PM BLDC drives with petal-wave current supply." IEEE Transactions on Industrial Electronics 62.7 (2015): 4034-4043.
25. Cai, H., Wang, H., Li, M., Shen, S., Feng, Y. and Zheng, J., 2018. Torque Ripple Reduction for Switched Reluctance Motor with Optimized PWM Control Strategy. Energies, 11(11), p.3215.

26. Li, H., Bilgin, B. and Emadi, A., 2019. An Improved Torque Sharing Function for Torque Ripple Reduction in Switched Reluctance Machines. IEEE Transactions on Power Electronics, 34(2), pp.1635-1644.

27. Xu, A., Zhang, W. and Ren, P., 2018, May. Comparison of torque ripple reduction for switched reluctance motor based on DTC and DITC. In 2018 13th IEEE Conference on Industrial Electronics and Applications (ICIEA) (pp. 1727-1732). IEEE.

28. Yan, N., Cao, X. and Deng, Z.Q., 2018. Direct Torque Control for Switched Reluctance Motor to Obtain High Torque-Ampere Ratio. IEEE Transactions on Industrial Electronics.

29. Shin, S., Hikaru, N., Kosaka, T. and Matsui, N., 2018, May. Torque Ripple Minimization Control of SRM Based on Novel Motor Model Considering Mutual Coupling Effect. In 2018 International Power Electronics Conference (IPEC-Niigata 2018-ECCE Asia) (pp. 3418-3425). IEEE.

30. Mehta, S., Kabir, M.A. and Husain, I., 2018, September. Extended Speed Current Profiling Algorithm for Low Torque Ripple SRM Using Model Predictive Control. In 2018 IEEE Energy Conversion Congress and Exposition (ECCE) (pp. 4558-4563). IEEE.

31. Debouza, M., Al-Durra, A., Hasanien, H.M., Leng, S. and Taha, W., 2018, October. Optimization of Switched Reluctance Motor Drive Firing Angles Using Grey Wolf Optimizer for Torque Ripples Minimization. In IECON 2018-44th Annual Conference of the IEEE Industrial Electronics Society (pp. 619-624). IEEE.

32. Velmurugan, G., Bozhko, S. and Yang, T., 2018, November. A Review of Torque Ripple Minimization Techniques in Switched Reluctance Machine. In 2018 IEEE International Conference on Electrical Systems for Aircraft, Railway, Ship Propulsion and Road Vehicles \& International Transportation Electrification Conference (ESARS-ITEC) (pp. 1-6). IEEE..

33. Maini, C., Gopal, K. and Prakash, R., 2013, November. Making of an 'all reason'electric Vehicle. In Electric Vehicle Symposium and Exhibition (EVS27), 2013 World (pp. 1-4). IEEE.

34. Krishnan, R., Arumugan, R. and Lindsay, J.F., 1988. Design procedure for switched-reluctance motors. IEEE Transactions on Industry Applications, 24(3), pp.456-46

35. Fahimi, B., Suresh, G., Mahdavi, J. and Ehsami, M., 1998, May. A new approach to model SRM drive application to dynamic performance prediction, control and design. In Power Electronics Specialists Conference, 1998. PESC 98 Record. 29th Annual IEEE (Vol. 2, pp. 2097-2102). IEEE.

36. Ohyama, K., Aso, K., Nashed, M.N.F., Fujii, H. and Uehara, H., 2005. Design using finite element analysis of SRM for electric vehicle. Journal of Asian Electric Vehicles, 3(2), pp.793-800.

37. Li, J., Sun, H. and Liu, Y., 2010, October. New rotor structure mitigating vibration and noise in SRM. In Information Networking and Automation (ICINA), 2010 International Conference on (Vol. 2, pp. V2-80). IEEE.

38. Choi, Y.K., Yoon, H.S. and Koh, C.S., 2007. Pole-shape optimization of a switched-reluctance motor for torque ripple reduction. IEEE Transactions on Magnetics, 43(4), pp.1797-1800.

39. Sadeep Sasidharan and T. B Isha, "SRM for EV : The Future", Third Biennial International Conference on Power and Energy Systems: Towards Sustainable Energy (PESTSE), Jan 18-20 2018 